\title{
EL POETA Y LA MUERTE EN LA POESÍA DE ARMANDO URIBE ARCE. HACIA UNA FÍSICA-POÉTICA DE LA MUERTE
}

\section{Gilberto Triviños* y Pedro Aldunate**}

\section{RESUMEN}

El siguiente artículo sitúa la escritura poética de Armando Uribe Arce en la tradición literaria chilena del siglo XX, especialmente en la línea de escritura figurativa sobre la muerte. La poesía de Uribe Arce es leída como transgresión poética en tanto propone la figuración del cadáver, estableciéndose como un caso particular de escritura en el contexto de la literatura chilena. En este sentido, la poesía de Uribe Arce reescribe, a través de distintas variantes, la tradición de los encuentros entre el poeta y la muerte. Por último, se describe la figura del autor como sujeto ético que se construye a sí mismo a partir de la relación que establece con la muerte en su obra.

Palabras claves: Poeta, muerte, cuerpo, cadáver, tradición, transgresión, figuración de la muerte, figura de autor, física, metafísica, ética, huella.

\section{ABSTRACT}

This article places Armando Uribe Arce's poetic writings in the twentieth century Chilean literary tradition, especially in the line of figurative writing about death. Uribe Arce's poetry is read as poetic transgression, since it proposes a figuration of the corpse, establishing a particular case of writing in the context of Chilean literature. In this sense, Uribe Arce's poetry up dates, through different variants, the tradition of the encounter

* Dr. en Literatura (EE.UU.). Profesor Titular de la Facultad de Humanidades y Arte de la Universidad de Concepción, Concepción, Chile. Crítico literario. Premio "Mejores Obras Literarias", Mención Ensayo, del Consejo Nacional del Libro y la Cultura, por el libro La polilla de la guerra en el Reino deChile (1995).E-mail: gtrivino@udec.cl

${ }^{*}$ Dr. $\odot$ en Literatura Latinoamericana (Universidad de Concepción, Chile). Poeta y crítico literario. E-mail: pedroaldunate@gmail.com 
between the poet and death. And finally, it describes the figure of the author as an ethical subject that builds himself from the relation that he establishes with death in his play.

Keywords: Poet, death, body, corpse, tradition, transgression, death figure, the author's figure, physics, metaphysics, ethics, trace.

Recibido: 17.03.2006. Aceptado: 08.05.2006.

"Ah, muerte, ven, te necesito cerca para escribir mis versos, dímelos tú, por más que adversos me sean, dicta lo que escribo". Armando Uribe ArCe

\section{INTRODUCCION}

L OS ULTIMOS libros publicados por Armando Uribe Arce $(1933)^{1}$ actualizan la práctica poética como ejercicio ético-estético de aproximación y comprensión de la muerte entendida, sobre todo, como hecho físico sucedido en el cuerpo ${ }^{2}$. La Vieja es no sólo el gran tema de esta poesía, sino su obsesión más profunda y el motivo de su transgresión ${ }^{3}$. Huella perturbadora de la tarea de morir y de escribir, de la afirmación de la soledad donde amenaza la fascinación (Blanchot 2000: 27), la obra, en el sentido de entrega a lo incesante, a lo interminable, del autor de Los ataúdes reelabora, a través de diversas variantes, la tradición de los encuentros del poeta con la muerte. Escribir es, en este caso, un ejercicio del cuerpo mediante el cual el poeta expresa poéticamente su voluntad de relación profunda con la "alteridad radical" designada con el nombre muerte. El gesto específico de su inscripción perturbadora en la historia aún no escrita de las relaciones entre escritura y muerte en la poesía latinoamericana es la amplificación hiperbólica que descubre, sin “esperanzadas fantasmagorías”, sin consuelos metafísicos, el cadáver, el cuerpo muerto con todos los detalles escabrosos de su descomposición. Escribir, dice Deleuze, es devenir otra cosa que escritor. Devenir, replica Uribe Arce, es encontrar la zona de indiscerni-

\footnotetext{
${ }^{1}$ Poeta chileno perteneciente a la generación del 50'. Premio Nacional de Literatura, año 2004. Los textos a los que haremos referencia en este artículo son los siguientes: Por ser vos quien sois (1989), Losataúdes/ Laserratas (1999), A peor vida (2000), Verso bruto (2002) y Demuerte (2004). Sobre la generación del 50, ver Muñoz y Oelker (1995:323-335), especialmente su referencia a los estudios de Pedro Lastra, preocupado de determinar con precisión las figuras y las promociones de esta generación, incluyendo a Uribe Arce con ciertas dudas sobre su novedad.

${ }^{2}$ Una primera aproximación a la relación poesía-muerte en este autor se encuentra en la tesis de Magíster en Literatura Hispanoamericana "La construcción autorial de Armando Uribe Arce: el autor, la obra y la muerte” de Pedro Aldunate (Universidad de Concepción, 2004).

${ }^{3}$ Utilizamos los conceptos de transgresión y edicto en el sentido de Bataille (1992).

4 "Devenir no es alcanzar una forma (identificación, imitación, Mimesis), sino encontrar la zona de vecindad, de indiscernibilidad o de indeferenciación tal que ya no quepa distinguirse de una mujer, de un animal o de una molécula" (Deleuze 1996:12).
} 
bilidad o indiferenciación ${ }^{4}$ tal que ya no es posible distinguirse de un anatomista fascinado por la mirada del cadáver tapada por la percepción poética y metafísica de nosotros mismos: la muerte-propia observada en el cuerpopropio yacente, en el "hotel deshabitado" que se llama ataúd.

¿Cuál es el gesto de la poesía ante el gesto nulo de la muerte? y ¿qué relaciones se descubren en esa proximidad de la poesía con la muerte? Dichas preguntas apuntan, por una parte, hacia una relación particular entre la literatura y la muerte, pero también, y simultáneamente, entre la literatura y la vida, ya que es el cuerpo del autor el que es figurado como imagen límite de sí mismo en su condición de cuerpo "después de la muerte", en su estado de cuerpo sin vida. La poesía es, de esta forma, pregunta por el cuerpo y relación de tales sucesos donde, precisamente, la conciencia de ese cuerpo estalla y se desintegra.

El mapa del significante muerte en la escritura de Armando Uribe Arce no lo forma una única figuración de la cosa que "no es mujer ni es hombre" sino varias y sucesivas figuraciones que constituyen la posibilidad misma del lenguaje poético y la capacidad de establecer relaciones con la muerte desde el texto entendido como huella del autor ${ }^{5}$. La proliferación incesante de los signos de la muerte en un cuerpo y el diálogo imposible con ella constituyen el juego trágico en el que la voz del poeta fascinado hace posible su muerte anticipándola, inventándola ahí donde el "yo" de los demás no da ninguna luz sobre su propio fin. Leemos la muerte en el texto poético y ella se oculta en el mismo instante en el que se revela su extrañeza radical: "No estás en parte alguna y no eres muerte", "Viuda sin sexo, yerma / muerte, es tu turno ahora" (Uribe Arce 2000:156).

\section{TRADICION Y TRANSGRESION}

La poesía chilena contemporánea se singulariza por un repertorio abundante de escritura figurativa sobre la muerte, no desde ella, como lo recuerda Lihn en su estremecedor Diario de muerte, porque nadie escribe desde el más allá. Ese repertorio constituye la memoria de una relación en particular: la historia imaginaria de los encuentros del poeta con la muerte. La poesía de Mistral, Neruda, Huidobro, Pablo de Rokha, Parra, Rojas, Teillier o

\footnotetext{
${ }^{5}$ Seguimos aquí el pensamiento de Jacques Derrida, según el cual la escritura es huella y, por lo tanto, no depende de una presencia implicada en un "habla supuestamente originaria" (Derrida, 1971). Las figuras del autor en el texto poético son, en este sentido, huellas de un cuerpo-autor. Esta perspectiva permite precisar la relación entre escritura poética y muerte, ya que, precisamente, es el cuerpo del autor el que experimenta el hecho de morir. De esa proximidad física con la muerte la escritura poética es huella y, por lo mismo, memoria y relación -en el sentido de relatodel diálogo del poeta con la muerte.
}

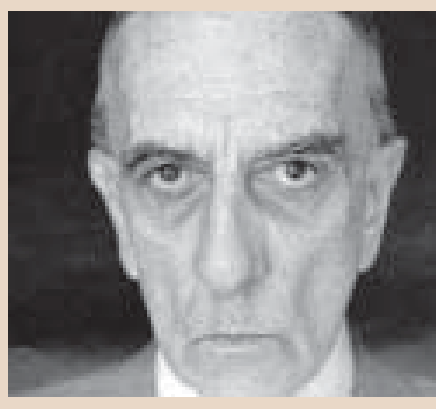

A. Uribe Arce

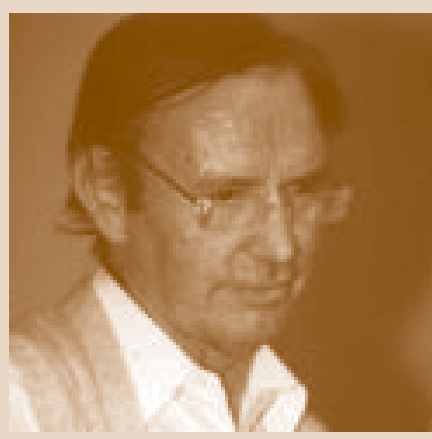

J. Teillier 


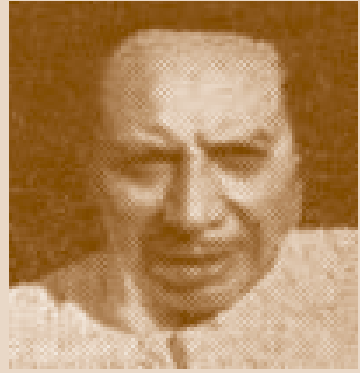

R. del Valle

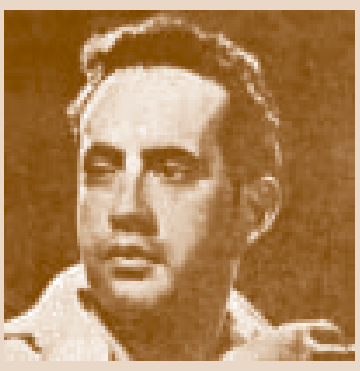

C. de Rokha

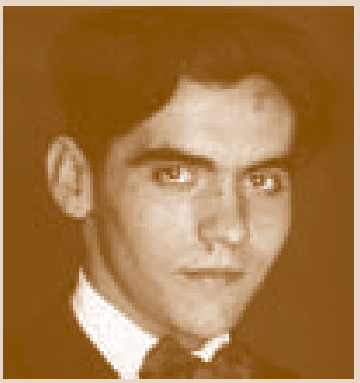

F. García Lorca

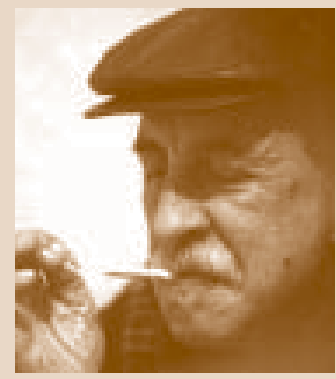

G. Millán
Lihn, pero también la de Pezoa Véliz, Rosamel del Valle, Carlos de Rokha, Zurita, Millán, Rubio, Barrientos, Stella Díaz, Hahn, Martínez o Harris, convierte en tradición de escritura las ficciones del diálogo del poeta con la muerte. La Señora es en ellas un fenómeno cotidiano, previsible, "tan cerca de ti como el feto de su madre o la semilla de su fruto", pero a la vez una negatividad que aterroriza porque es "simplemente otro ser, y su conexión contigo una fisura / aunque lo alumbres y te pudras para que sea" (Lihn 1989: 49). Próxima y lejana, inmanente y trascendente, insólita y familiar, fenómeno y misterio a la vez. La literatura y la filosofía de la muerte dialogan, en este caso, con singular fertilidad. Una y otra emiten, no obstante sus diferencias específicas, un bello balbuceo metafórico en la zona muda misma creada por el Hapax contradictorio que "es como un clavo que el más allá clava en el más acá ¡Tan cerca y tan lejos!" (Jankélévitch 2002: 20), "que nos ronda como avispa / o tábano o abeja -su picadura que nos crispa; / y ella al picar se muere, mas no muestra / su paradero. Muerte, ¿dónde está tu aguijón?" (Uribe Arce 2004:41), que es como la puerta de entrada a "otromundo que es otro mundo, absolutamente otro y absolutamente en otra parte (un mundo distinto a este y fuera de este), y a pesar de todo presente por todas partes, como Dios omnipresente y omnisapiente, que está en los dos lados a la vez, del lado de acá y del lado de allá" (Jankélévitch 2002:21). El diálogo impensado de Uribe Arce (“¿dónde está tu aguijón?”) con García Lorca (“¿dónde está mi sepultura?") hace aquí visibles las secretas correspondencias dentro de la gran poesía hispánica sobre el misterio de la muerte. La poesía chilena y la poesía española forman en este aspecto unas bellas bodas, siempre "fuera" y "entre" dos, entre todos los dos que se quiera, para hallar, encontrar, robar los nombres de la zona muda: murmullo de "entre dos" soledades en el que "cada uno lleva su botín, sin que por eso deje de juntarse con los demás; así es cómo se elabora un devenir, cómo se pone en movimiento un bloque, que ya no es de nadie, sino que está entre todo el mundo, como un barquito que unos niños sueltan y pierden, y que otros roban" (Deleuze y Parnet 1997:13-14). Es el barquito-poesía donde la conjunción $Y$, cifra del concierto de las voces castellanas que exploran el misterio, no señala una reunión ni una yuxtaposición, sino el nacimiento de un tartamudeo, el movimiento de un bloque, el trazado de una línea quebrada (Deleuze y Parnet 1997:14). Rubén Darío Y Juan Ramón Jiménez Y Miguel Unamuno $Y$ Amado Nervo $Y$ Pablo Neruda $Y$ Federico García Lorca $Y$ Gabriela Mistral Y Ana Rossetti Y Vicente Huidobro Y Antonio Machado $Y$ Eliseo Diego Y Antonio Gamoneda Y Carlos de Rokha Y José Olivio Jiménez Y Gonzalo Millán Y Juan Carlos Mestre Y César Vallejo Y Rafael Alberti Y Nicanor Parra Y Miguel Hernández Y Gonzalo Rojas Y... Línea de fuga activa y creadora que lleva a esta multiplicidad de autores a constituir una banda, en el sentido de Deleuze, de sondeadores del Misterio: la tribu de poetas cuyas sondas devienen pulso herido que sondea las cosas del otro lado: 
El poeta espiritualista (Nervo) me ha torturado más de lo que yo creía. "Al volver, alguien ha entrado" me ha dejado meditando, con el corazón oprimido, con la frente calenturienta. ¿No sondearemos nunca el Misterio? ¿No lo dominaremos jamás? ¿Seguirá siendo nuestra eterna tortura, nuestra obsesión desesperante?

Yo también he corrido toda mi vida como Sabino el de "El Fantasma" detrás de lo sobrenatural de la inmutable Esfinge.

Todos estos pensadores de los problemas de ultratumba, ¿llegarán algún día a levantar la enorme losa que oculta los misterios del sepulcro? Yo quisiera forcejear con ellos, yo quisiera ayudarlos en su combate contra el Argos que guarda este misterio, contra el dragón celoso de su tesoro (Huidobro 1976:710).

Es posible reconstituir, pues, la historia del imaginario poético chileno de la muerte. Los versos finales del célebre poema "Nada" de Carlos Pezoa Véliz parecen prefigurar, en este aspecto, un destino o programa poético nacional: "Tras la paletada nadie dijo nada, nadie dijo nada..." (Pezoa Véliz 1912:79). Los puntos suspensivos que siguen a nada son la imagen misma del designio tal vez destinado al fracaso desde siempre: llenar el hueco, el vacío, la nada inenarrable abierta por la muerte, ese "otro-mundo que es otro mundo, absolutamente otro y absolutamente en otra parte (un mundo distinto a este y fuera de este)".

"Los sonetos de la muerte", "Lápida filial", "Muerte de mi madre, "Paraíso", "Madre Mía", "Canto que amabas" y "Cuando murió mi madre", entre otros poemas de Desolación, Tala, Lagar, Ternura y Poema de Chile, cifran bellamente la transfiguración mistraliana de la negatividad de la ContraMadre del Mundo, disgregadora impura, mañosa empadronadora y cruel oledora de los nacidos de "Canción de la muerte" (Ternura), en la positividad que abre la puerta a un más allá de la muerte en el que el Tiempo queda en el umbral, como los perros vagabundos de "Paraíso". Los muertos no dejan de ser en esta poesía. Fueron antes de la muerte y continúan siendo después de su muerte. "Paraíso", donde se cuenta el misterio de la transfiguración de los cuerpos muertos en cuerpos gloriosos, "un cuerpo glorioso que oye / y un cuerpo glorioso que habla / en el prado en que no habla nada" (1992:331); "Lápida filial”, donde la hija clama por la resurrección de su madre "si existe la hora, si es cierto el día, / para que Cristo os reconozca / y a otro país deis alegría “(1992:305); “Ceras eternas”, donde los brazos y los ojos del amado que duerme en la tierra quedan seguros, distendidos, sosegados, sin ninguna memoria de los horrores de su descomposición; "Locas letanías", donde la hija pide a Cristo, el resucitado que sabe de ruta y de tránsito, llevar a su madre muerta a un cielo de madres que arrullan a sus hijos recobrados o apresuran "con su silvo / a los que gimiendo vamos" (1992:319); "Fuga”, donde se revela el secreto doloroso de la hija que libera a

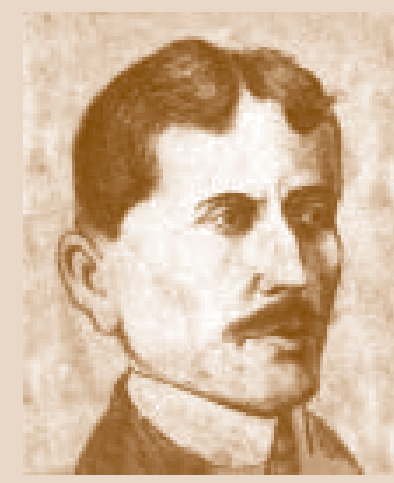

C. Pezoa Véliz

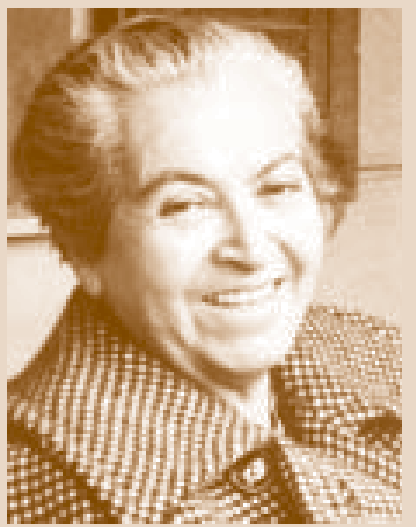

G. Mistral 


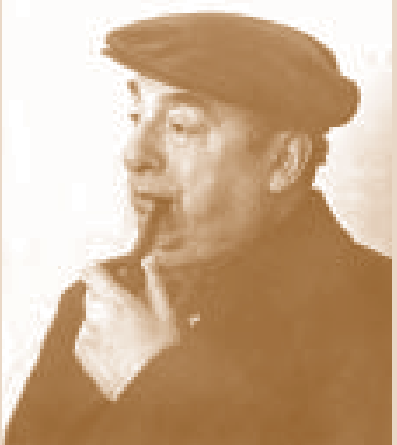

P. Neruda su madre de dioses crueles para llevarla a un Dios que es de ellas (1992:303); y "Vieja", donde la misericordiosa vela la muerte de la anciana de ciento veinte años "diciéndole la muerte lo mismo que una patria; dándosela en la mano como una tabaquera, / contándole la muerte como se cuenta a Ulises, / hasta que se la oiga y me la aprenda" (1992:425), son sólo las cifras más bellas del pasaje de los muertos de "Gea hasta Dios", de la sepultura sin fetidez ni "crac crac crac de huesos" al prado en que nada tiembla y los cuerpos gloriosos se acuerdan del triste tiempo en que los dos tenían Tiempo y de él vivían afligidos (1992: 331).

Poesía, pues, de la fuga de la verdad pavorosa de la tumba. La místicautópica (sueño) mistraliana trasciende así la desgarradura del cuerpo muerto por los "dioses de debajo". Silenciamiento ostentoso de la disolución misma del pensador que recuerda su mortalidad: "carne fatal, delante del destino desnuda / carne que odia la muerte y tembló de belleza" (1992:9). Acto de redención metafísica que lleva a los muertos a no morir. La escritura que establece una relación profunda con la muerte que no es el cese del ser no se detiene en el desengañador pasaje del cuerpo por el reino del gusano. Le importa sólo el viaje del alma felizmente olvidada del desgarro físico en el hoyo inmundo, la unión con el Señor fuerte que llama en los bronces y en el pórtico mismo de toda su obra ("El pensador de Rodin"). Exilio de la patria -eternidad, paraíso, prado en que nada tiembla- y promesa de la patria. Triunfo de la vida en el reino mismo de la muerte. La poesía de la mujer que camina "loca y contenta" a su propia-muerte testimonia así el secreto de su propia búsqueda de relaciones de soberanía frente a la "Contra-Madre del Mundo" de la que se huye con palabra estremecida en "Canción de la muerte" (Ternura). El secreto de lograr unirse fuertemente a su muerte: "Una voz dijo: 'Vive para aprender la muerte'. / Con sólo que camines te la irás encontrando" (1992: 847).

La mirada refractaria a la visión del cadáver predominante en la literatura y la filosofía de Occidente ${ }^{6}$ es un rasgo también característico de la poesía de Neruda, preocupada sobre todo de transfigurar el cuerpo en materia eternizada. El hablante de los poemas Las piedras del cielo dice por ello "no soy capaz para tantos misterios: / abro los ojos y no veo nada: / toco la tierra y continúo el viaje" (Neruda 1993:564). Abro los ojos, pero no quiero ver nada, porque lo que veo está ahí, señalándome, dibujando los contornos de mi cuerpo virtualmente podrido. Un sueño mineral cierra los ojos del poeta y tapa la podredumbre impostergable de la materia. Este escamoteo del cadáver se expresa, sin duda, en el poema "Sólo la muerte" de Residencia en la

\footnotetext{
6 "La metafísica no reserva lugar alguno al cadáver. Ni por lo demás, al ser vivo. Cuanto más abstractos e impersonales nos volvemos, ya sea a causa de conceptos o de prejuicios, los filósofos y las mentalidades ordinarias se mueven por igual en la irrealidad, más inconcebible parece la muerte próxima, inmediata" (Cioran 1998: 125).
} 
Tierra II: "Hay cadáveres, / hay pies de pegajosa losa fría / hay la muerte en los huesos", pero después, "Yo no sé, yo conozco poco, yo apenas veo" (Neruda 1967:213-214). Mirada que no mira al muerto. Utopía de la poesía que rehúye, precisamente, la visión del cadáver devenido lugar de la fiesta del gusano y de la rata. No seremos carroña, ni haz de huesos, ni resto podrido. Seremos fulgor infinito, luz de la eternidad, fuego enterrado, amantes muertos que esperan dormidos a sus amadas vivas, aves, piedras oscuras que se lleva el río... O tal vez eso que sueña el poeta preparado para cantar y para morir (“¿Ahí está el mar? Muy bien, que pase”): ser un modesto langostino, una gota roja del mar. Una palabra nombra con gran fuerza sugestiva la bella fuga de la visión del cadáver en el ataúd: resurrecciones. Forma de resistir la muerte unificadora de la vasta obra de Neruda imantada por la sed de lo infinito, por la hostilidad a las cenizas, por todas las formas de la fertilidad, por las escandalosas bodas de la piedra con la carne: "lo veo en su ataúd y resurrecto", "vivir, morir, en ese gran silencio / de la dureza, madre del fulgor", "mi deseo es vivir, morir, vivir".

La palabra poética en Vicente Huidobro ficcionaliza, por su parte, una relación lúdica de seducción mutua entre el poeta y la muerte (Triviños 1996), tal como se puede leer en el poema "El terror de la muerte" del libro La gruta del silencio. La muerte entra sigilosa a la habitación del yo -figura del poeta- $y$ salta, felinamente, sobre su presa: muerte femenina, acechante, muerte-mujer deseada por el cuerpo paciente del poeta:

Yo he sentido a la muerte que ha entrado a mi cuarto

(...)

Desde ahí me está espiando callada

Y me tiene los ojos clavados

Que relumbran como ojos de gata,

Llenos de codicia, de futuros espasmos.

Me mira, me analiza, me observa,

Y se recoge en la actitud de un felino

Que va a saltar sobre su presa

Y que siente el estertor del herido.

(...)

Y sé bien que la muerte ha de besarme

Y que su beso será inevitable...

Acaso yo algún día mendigaré su beso

(Goic 2003:169-170).

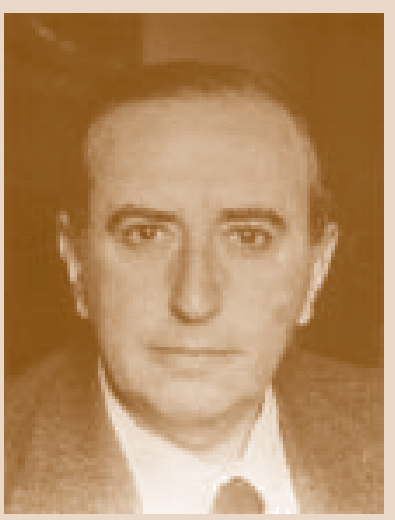

V. Huidobro

La poesía es, de este modo, deseo de muerte: de una muerte futura y necesaria. Apuesta suprema en la que Huidobro-Altazor cae jugando con la muerte: "Eres tú el ángel caído / la caída eterna sobre la muerte / la caída sin fin de muerte en muerte" (1997:27). El sujeto maldice y, a su vez, desea su propia-muerte, en un juego incansable de contradicciones. Creacionismo y 


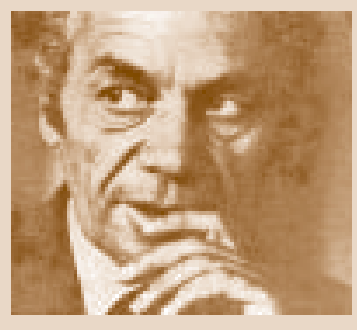

N. Parra

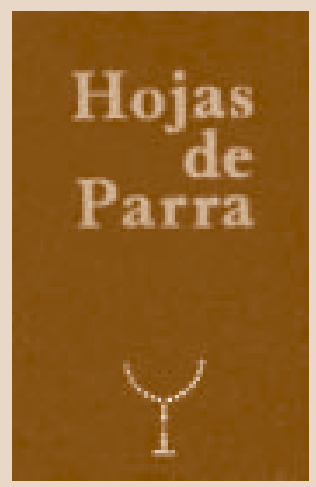

agonismo, voluntad poética y voluntad de morir en el acontecimiento de la poesía. El sujeto del texto se hunde en la muerte y se lleva consigo la propia imagen especular del autor, su figura: "Aquí yace Altazor, azor fulminado por la altura / Aquí yace Vicente, antipoeta y mago" (Huidobro 1997:72). El poema deviene así la morada de un cuerpo transmutado en la figura inmortal de Altazor al mismo tiempo que el cadáver desaparece en la imagen eternizante del mar: "Se abre la tumba y al fondo se ve el mar" (Huidobro 1997).

La risa antipoética de Parra, proveniente del realismo grotesco de la cultura popular, parece liberarse del interdicto de la visión del cadáver. "El AntiLázaro" testimonia una transgresión que finalmente es ilusoria. El muerto que duerme sin los aguijonazos de la duda es amo y señor de su propio ataúd. Nada falta en el sepulcro del feliz cadáver que la irónica voz de su Anti-Cristo exhorta a no desear la resurrección. Nada ni nadie testimonia aquí el "crac crac crac de los huesos" en la tumba. Este es el límite de lo decible del muerto en su ataúd. La antipoesía se fuga de la visión del muerto cuando se disuelve "como las baratas" en soluciones para insectos. Las metamorfosis del cuerpo roído por la muerte, sin embargo, ya están ahí, prefigurándose en el encuentro nocturno antipoetizado en el poema de la clausura festiva del dominio de las figuras bellas, castas y maternales de la poesía latinoamericana. La muerte vizcacha, lacha y borracha llega a la casa del poeta borracho, cabrón y desgraciado para echar una buena cacha. El viejo se resiste pero finalmente cede. Triunfo ostentoso de la seducción: la vieja cutufa se empelota y el viejo se lo enchufa (Parra 1985:116). Violación irreverente del misterio del pozo de Lascaux (Triviños 2001:131-132). Boda cómica que concluye, como en la Lisístrata de Aristófanes, con la reconciliación de los enemigos. Coito entre la muerte y el poeta devenidos viejos que hablan y se cruzan como una comadre con otra (Triviños 1996:75). Risa que parodia el sueño trascendentalizador de Mistral, los deseos eternizantes de Neruda y las acrobacias mortales de Huidobro. Relato irreverente de la relación muerte-erotismo que deja intacto el interdicto del ocultamiento del cuerpo en la sepultura. "El poeta y la muerte" prefigura en este sentido el "Anti-Lázaro", poema final de Hojas de Parra dominado por la figura del cadáver feliz, no ya en el "instante mortal" mismo, sino "más allá" de la muerte:

Muerto no te levantes de la tumba qué ganarás con resucitar (...) eres feliz cadáver eres feliz en tu sepulcro no te falta nada ríete de los peces de colores (...) 
no resucites por ningún motivo

no tienes para qué ponerte nervioso

como dijo el poeta

tienes toda la muerte por delante

(Parra, 1985:133-135).

La muerte por delante se menciona, pero no se poetiza. Las parodias del texto bíblico y de las gravedades vanguardistas de Mistral, Neruda y Huidobro permiten desviar, también en este caso, la mirada paradójicamente antipoética, grotesca, de la transformación del cadáver en "saco de podredumbre y de gusanos”. El poeta que fue profesor de física silencia de este modo lo que más tarde Lihn y Uribe Arce no dudan en figurar: la muerte entrando en el cuerpo unido a su muerte como los labios de Freud que se besan a sí mismos, la muerte royendo la carne del cadáver con malos olores en el cajón que es como un bote de las cloacas.

Enrique Lihn dibuja en su poemario póstumo Diario de muerte el cuerpo del moribundo. Cuerpo poético estoico que piensa el momento de la muerte y que se describe en la contradicción del Sí y del No a la Señora de cuyos "movimientos contradictorios puede esperarse la tempestad, y, también, la calma" (1989:47). El encuentro del poeta con la muerte se sitúa en el umbral mismo del instante mortal, no antes de la muerte ni después, sino cuando la "cosa sorda, muda y ciega" lo sorprende con la memoria de su mortalidad. Lihn es Aquiles conmocionado por la noticia de los heraldos negros: "Ahora sí que te dimos en el talón / La muerte de la que huyas / Correrá acompasadamente a tu lado / Buenas noches, Aquiles” (1989:47). Las preguntas por el "más allá” carecen de respuestas en el libro del andrógino perfecto. El mendigo del arte que nadie enseña y que no escribe "Contra la muerte, ni El arte de morir / ¡felices escrituras!” (Lihn 1989:51), descubre, precisamente, que debería aprender, para dolerse, desesperarse y morir, un lenguaje limpio como un cuerpo operado de todos sus órganos, "que viviera una fracción de segundo a la manera del resplandor / y que hablara lo mismo de la felicidad que de la desgracia / del dolor que del placer, con una sonriente / desesperación, pero esto es ya decir / una mera obviedad con el apoyo / de una figura retórica" (1989:14). Asedio a la zona muda con un lenguaje limpio. La escritura misma de Diario demuerte, libro del poeta que muere fiel a sí mismo ("Déjenme acabarme en mi ley...") y fiel a la alta potencia de la muerte ("Ella es simplemente otro ser, y su conexión una fisura...”), testimonia esta empresa (im)posible con sobrecogedora lucidez (Triviños 2005).

La tradición de los encuentros entre el poeta y la muerte testimonia, pues, con múltiples variantes la relación profunda entre poesía y muerte en la literatura chilena. Su estudio riguroso, que aquí sólo iniciamos, abre la posi-

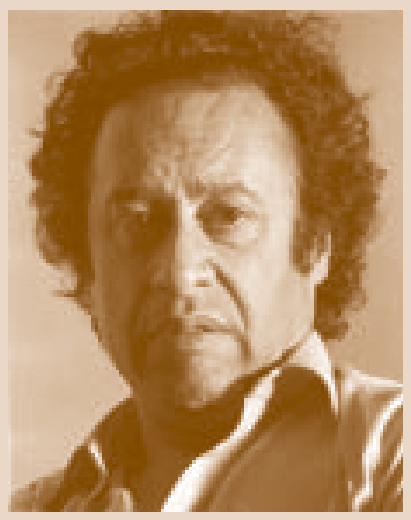

E. Lihn

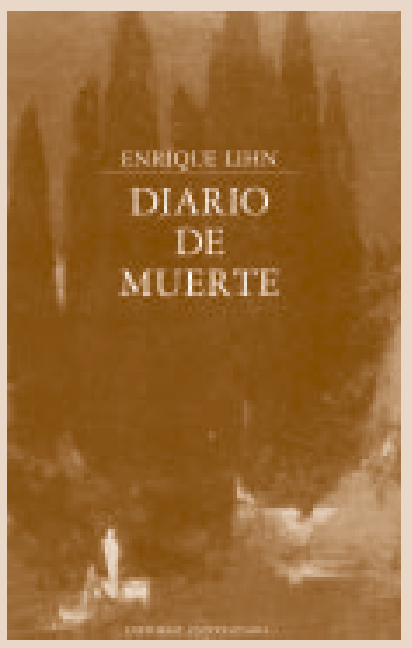

$71 \stackrel{\text { Atenea } 493}{\mid \text { | Sem. } 2006}$ 
bilidad de reconstituir la fascinante historia de nuestra poesía como poder y saber en el ámbito mismo del extremo que parece clausurar radicalmente todo poder $y$ todo saber:

(Sólo) se puede escribir cuando se es dueño de sí frente a la muerte y cuando se establecen con ella relaciones de soberanía. Pero si frente a la muerte se pierde la compostura, si ella es algo incontenible, entonces corta la palabra, no se puede escribir; el escritor ya no escribe, grita, un grito torpe, confuso, que nadie oye o que no emociona a nadie. Kafka siente profundamente que el arte es relación con la muerte. ¿Por qué la muerte? Porque es lo extremo. Quien dispone de ella, dispone extremadamente de sí, está ligado a todo lo que puede, es integralmente poder. El arte es dominio del momento supremo, supremo dominio (Blanchot 2000:82-83).

Las relaciones descritas descubren en qué sentido la poesía, arte del "momento supremo, supremo dominio", es capaz de establecer una relación de soberanía con la muerte. Mistral, Neruda, Huidobro, Parra, Lihn y Uribe Arce cifran sólo varias de las formas de esa relación. El estudio de las diferencias específicas, aquí sólo sugeridas, entre la visión ocultadora del cadáver (Mistral, Neruda, Huidobro, Parra) y la visión desublimadora que no silencia el relato de la muerte como pavorosa experiencia física del moribundo (Lihn) y del cadáver (Uribe Arce) no impide advertir lo también señalado por el autor de El espacio literario. Unos y otros poetas chilenos quieren, como Kafka o Gide, que la muerte sea posible, unos para alcanzarla, otros para mantenerla a distancia. Las diferencias entre los que escriben para morir y los que escriben para no morir se inscriben "en un mismo horizonte, el de establecer con la muerte una relación de libertad" (Blanchot 2000:86).

La escritura de Uribe Arce fascinada por la visión de los muertos en su sepultura constituye en este sentido fundamental una escandalosa transgresión del edicto predominante en la historia poética occidental de las figuraciones de la muerte. Los poemas-tumbas de Los ataúdes-Las erratas, pero también los de Por ser vos quien sois, Verso bruto, A peor vida y De muerte, cifran ejemplarmente la forma específica de tal transgresión: el traspaso tal vez más extremo de los límites de lo decible sobre el cadáver que la propia poesía chilena parece haberse impuesto tras la paletada de Pezoa Véliz. Es el pasaje, salto o devenir en el que los mismos muertos expulsados de la poesía se apoderan de la palabra para narrar los horrores de su disolución en el reino de los gusanos devoradores de los anos y de los vientres de hombres ajenos a Jehová, a Alah y a Buda. 


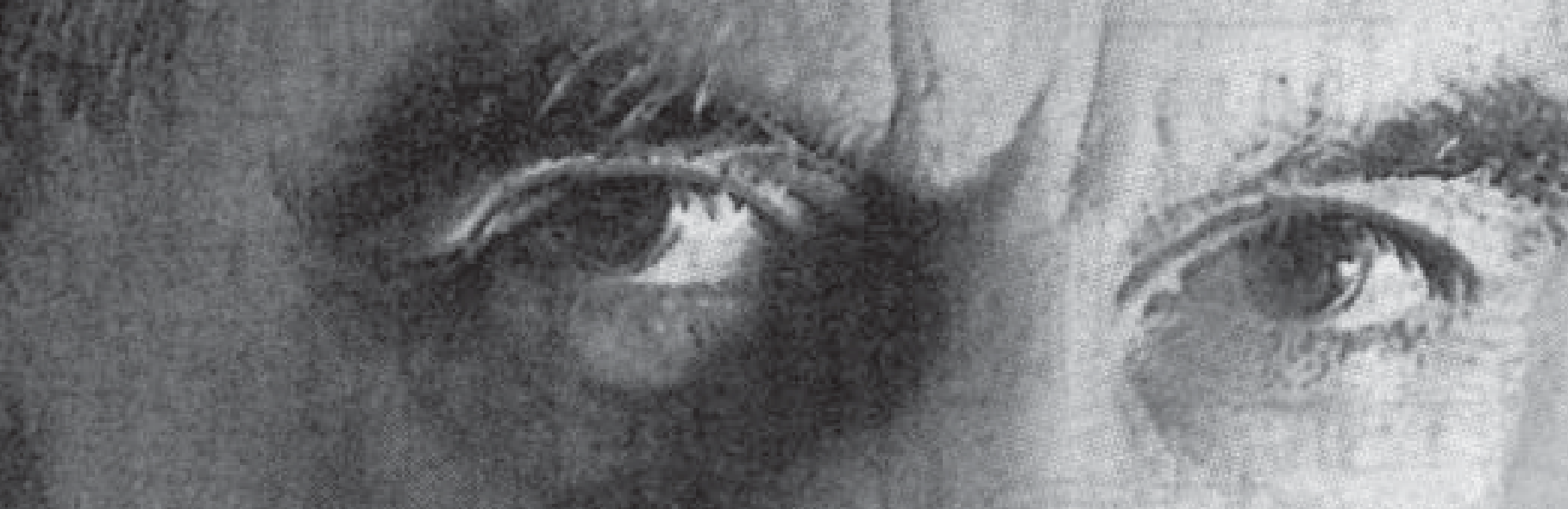




\section{LA MUERTE DE CRISTO EN POR SER VOS QUIEN SOIS}
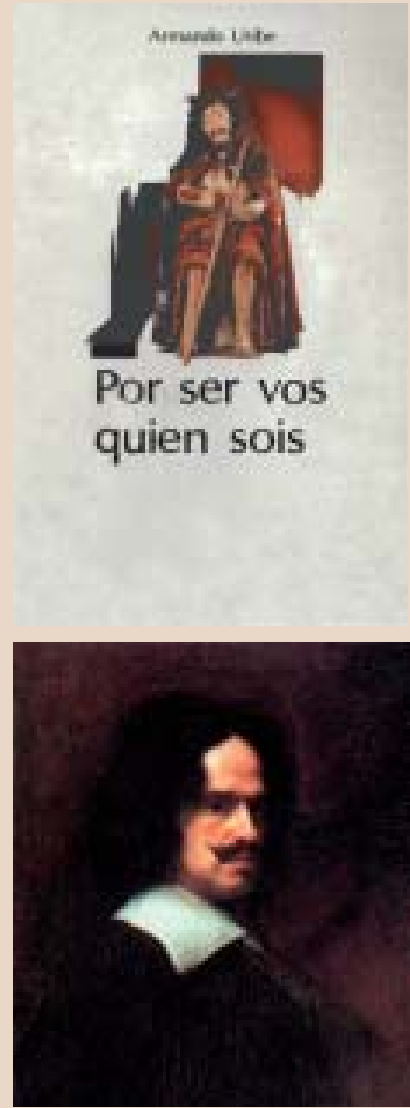

D. Velásquez

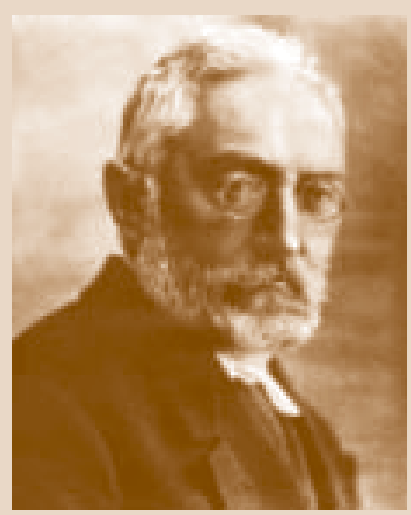

M. de Unamuno
El texto poético Por ser vos quien sois (1989) actualiza la relación entre el poeta y la muerte reescribiendo en clave invertida la historia del Crucificado. Escribir poesía, dice Uribe Arce en M emorias para Cecilia, es "relatar en susurro y disfrazado un secreto traspuesto, es expresar duda en forma de pregunta u otra" (2002b:60). La pregunta por la realidad física de la muerte erosiona radicalmente, en este caso, el sistema metafísico cristiano fundado en los misterios de la fe. La visión de la imagen de Cristo en la cruz provoca en el hablante la imprecación a Dios por su propia muerte: "Tú me conoces, yo no me conozco / tú me dirás quién soy cuando haya muerto" (Uribe Arce 1989:24). La interrogación es, pues, sobre el incómodo vacío que revela la identidad del ser. ¿Qué hay en ese lugar?: hay lo impensable, no concebible en el relato bíblico: sólo "la muerte horrible" del cuerpo. La muerte de Cristo sin signos de resurrección. No hay diferencias realmente entre el Hijo de Dios y el Hijo del Hombre. Uno y otro están igualmente sometidos a la "vieja ley" de la disolución del cuerpo y del abandono del padre: "Como cristos, no más que como cristos / como cristos no menos / (...) Dios mío, por qué me has abandonado. / ¿Cuándo te he abandonado? Nunca he estado contigo" (Uribe Arce 1989:35 y 39). La parodia y la ironía muestran de este modo el verdadero "secreto traspuesto" de Por ser vos quien sois: la tragedia individual de la mortalidad de la carne, la pregunta del hablante por la propia disgregación presentida más allá de la cruz, más acá del misterio: "Morí dos o tres veces. / No hay nada nuevo bajo el sol. / Bajo el sol envejeces / sin darte cuenta que se puso el sol. / No quedan ni las heces / de ti. Comiéronte a destajo / los dioses de debajo" (1989:45). El triunfo de la muerte sin promesa de resurrección es aquí, simétricamente inverso, por ejemplo, a su derrota, poetizada por Miguel de Unamuno en su bella evocación del primogénito de los muertos que convierte a la muerte "que es el fin (en) principio y soberana de la vida". Nada de Por ser vos quien sois evoca, en efecto, a El Cristo de Velásquez, regido poéticamente por la transfiguración del blanco cuerpo desangrado de Cristo ("Muerte de la muerte al fin") en figura radiante e irradiante de signos de trascendencia: "de tu cuerpo, que es cumbre de la vida, / resbalan cristalinas aguas puras / espejo claro de la luz celeste, / para regar cavernas soterrañas / de las tinieblas que el abismo ciñe" (Unamuno 1947:31). El Cristo de Uribe Arce tiene, empero, dos grandes dobles en el arte occidental: el Cristo muerto en la tumba (1522), de Hans Holbein el Joven, representación de "un hombre realmente muerto, del Cristo abandonado por el Padre (...) y sin promesa de la Resurrección" (Kristeva, I, 1990:249), y el Cristo en la cruz de Jorge Luis Borges, mortal que espera su fin sabiendo que no es un dios y que sólo es un hombre que muere con el día (1989, III:457). El príncipe Myshkin de El idiota se conmociona profunda- 

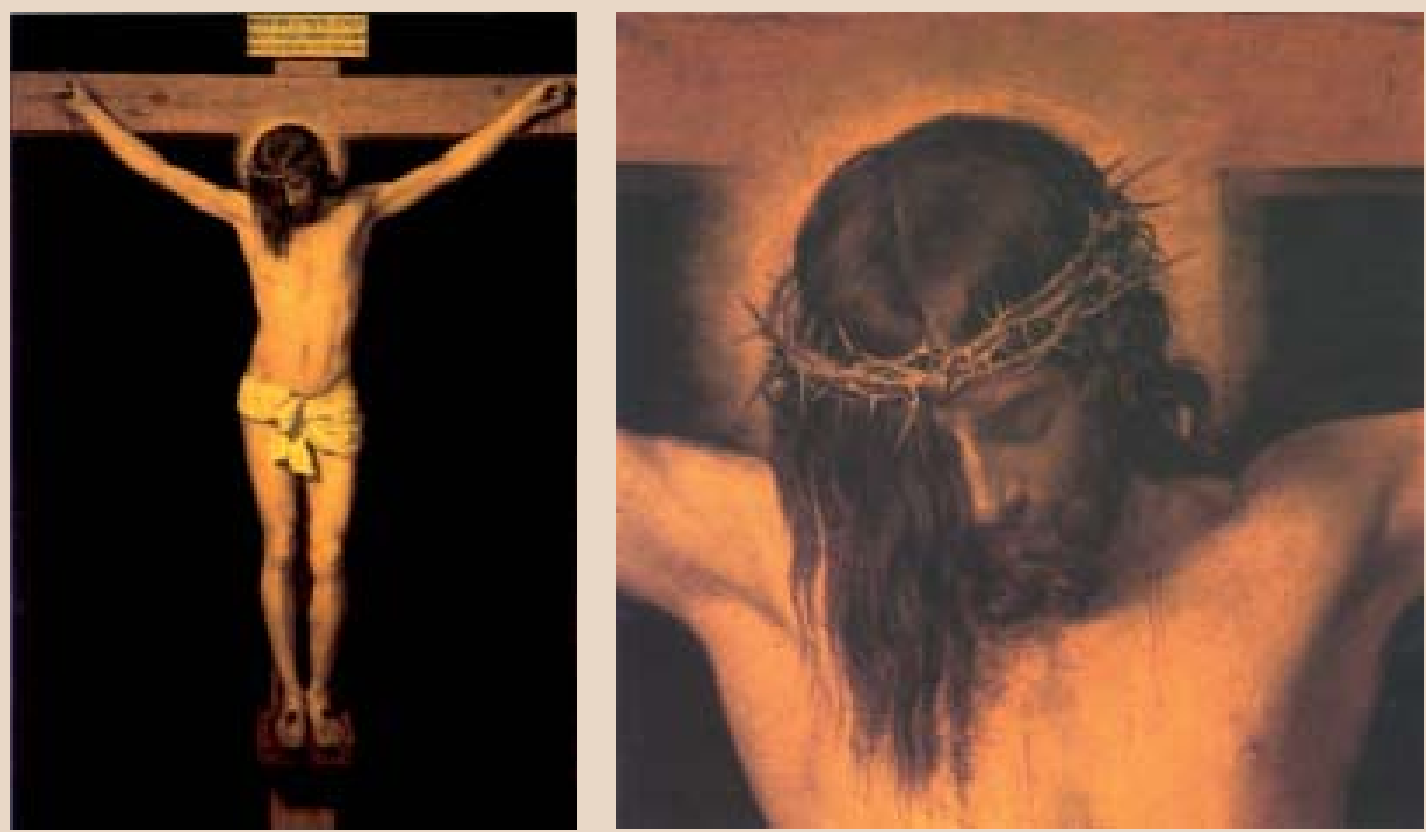

Cristo crucificado, de Velásquez

mente con la despiadada verdad del cuadro de Holbein. Su grito bien pudiera ampliarse a la sobrecogedora impresión que producen los Cristos sin futuro de Borges y Uribe Arce: “¡Este cuadro!... ¡Este cuadro! ¿Pero no sabes que al mirarlo un creyente puede perder la fe? (Kristeva, I, 1990:147).

Holbein, Borges, Uribe Arce: Cristo en el tiempo del abandono. Sumisión a la ley de la mortalidad ahí donde la divinidad ha huido dejando sólo "un gusano" para devorar el cadáver de su Hijo. Representación de la muerte humana sin mínima sugestión de trascendencia. Estallido extremo de toda "fantasmagoría" consoladora: "Eres polvo y serás polvo / polvo y no dios ni rey” (Uribe Arce 1989:58). Visión perturbadora del rigor mortis de Cristo que señala al lector-espectador su propio rigor mortis. Anatomía del así secesa: Nosotros, yo, tú, él, formamos, como el crucificado lo revela, la "hueste / de los futuros muertos sin futuro / y sin juego / de palabras de niños que no veremos luego". Poesía del desengaño radical donde la historia del crucificado se reescribe como un hecho íntimo que el creyente -el autor Uribe Arceobserva con un silencio que convierte a la práctica poética en una suerte de poesía-plegaria enunciada desde la posición extraña, pero previsible, del cadáver, ahí donde el ocultamiento del cuerpo sin signos de trascendencia
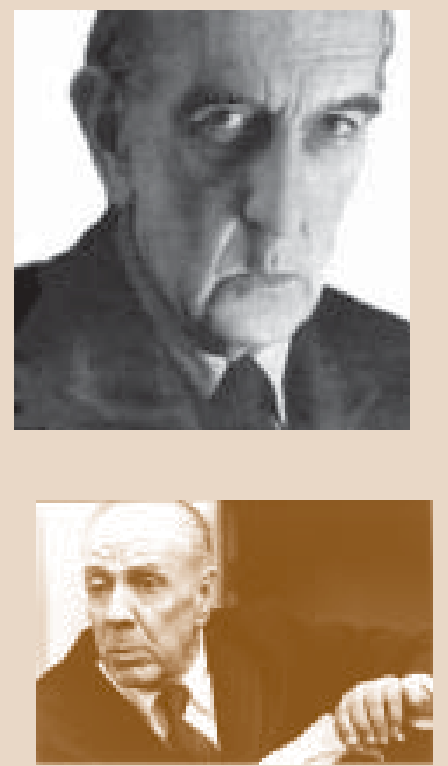

J.L. Borges 


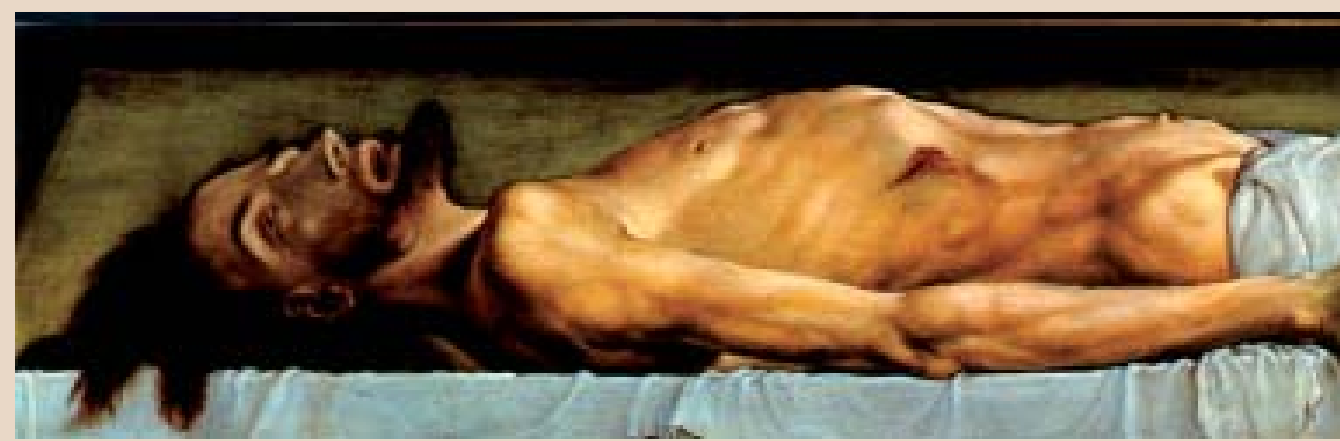

El cadáver de Cristo en el sepulcro (1521), de Hans Holbein, el Joven.

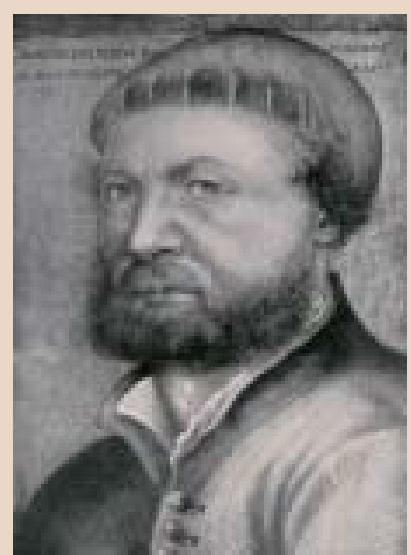

H. Holbein, el Joven

Ni el Dios viviente ni el Mesías muerto vienen a mi rescate bajo tierra, ni el cordero de Dios ni la paloma del espíritu santo. ¡ Virgen Santa! Pero viene el ratón agudo, es cierto. Viene un gusano viejo que me aterra. Viene la mosca, ojalá que me coma, y vengo yo que es lo que más me espanta.

(Uribe, 1989:52).

es ya imposible, en tanto el más allá metafísico sólo se hace posible a partir del reconocimiento de ser mortal, "soberanamente, extremadamente mortal".

La poesía que despoja al cadáver de todo signo de continuidad de su ser, sin embargo, es también rebelión, ira, imprecación y pregunta desgarrada: "Desde el fondo del hoyo a Ti Señor te llamo. / ¡hasta cuándo! hasta cuándo ¿hasta cuándo? / Dime Señor ¿qué te has figurado?” (1989:47). El cadáver siempre derecho, muy tranquilo, "hasta que sude su carroña", tiene en este aspecto gran interés en la tanatografía de Uribe Arce. Es el estado de los personajes (los muertos, el muerto, el cadáver, NN, Cristo, nosotros, yo, Cecilia) donde explota toda conciencia del yo y todo sistema de creencias. Ahí, precisamente donde la tumba masca los cadáveres a dentelladas "y en su pudridero brillan el peroné y la tibia ahuecada", se vislumbra una pequeña verdad, inadmisible para el creyente pero valiosa para el muerto comido en el tiempo del abandono de los "grandes dioses". El cadáver es el estado de la persona en el que explota toda conciencia del yo y todo sistema de creencias: 
"por la pura, por fregar y barrer delante de la casa". Escribe para hacer posible su propia-muerte, para la tarea que constituye la "vocación humana" misma del hombre: volverse "soberanamente, extremadamente mortal":

¿Puedo morir? ¿Tengo el poder de morir? Esta pregunta sólo tiene fuerza cuando se rechazaron todas las escapatorias. Sólo cuando se concentra enteramente sobre sí, en la certeza de su condición mortal, la preocupación del hombre es hacer posible la muerte. No le basta ser mortal, comprende que debe volverse mortal, que debe ser dos veces mortal, soberanamente, extremadamente mortal. Esa es su vocación humana. En el horizonte humano, la muerte no es lo que está dado, es lo que hay que hacer: una tarea, aquello de lo que nos apoderamos activamente, lo que se hace fuente de nuestra actividad y nuestro dominio (Blanchot 2000:87-88).

La "Nota" de Las erratas del "tremebundo" libro Los ataúdes-Las erratas cifra la creación del vínculo del cual el poeta que espera la fosa "es juez, hace su muerte, se hace mortal y así adquiere el poder de hacer y da a aquello que hace sentido y verdad" (Blanchot 2000: 88). Poder de hacer, de dar sentido y verdad, sin el cual la escritura de Uribe Arce sería sólo un "grito torpe, confuso, que nadie oye o que no emociona a nadie". La conciencia de la propia muerte, la contención del espanto por los terrores de la fosa, el rechazo del llamado salvaje de las divinidades de la disolución, la aceptación serena de la propia muerte (pre)sentida en lo más cercano al sujeto (el propio cuerpo), testimonian el mayor triunfo del hacedor de su muerte: logro de un dominio de sí frente al fin que, haciendo posible la muerte, hace plenamente humana la vida. Como Kafka, según el cual lo mejor que ha escrito se basa en la capacidad de poder morir contento, Uribe Arce parece escribir para unirse fuertemente a la muerte. No para huir ni disimularse frente a ella, sino para hacerla cercana, segura. Es la creación de la forma de libertad frente a lo extremo que la mencionada "Nota" testimonia bellamente en el pórtico mismo de Laserratas: "Me retiro a mi casa. Me preparo / a morir. No digo a bien morir; / a morir solamente. ¡Mi casa! / Lugar transitorio, como el / siguiente. Pero este último será un tránsito que / no lleva a ninguna parte. Satis- / facción de aceptarlo. Ya está / bueno ya de la vida / Estamos viejos y no estamos / muertos -es un estado incómodo"(1999:15-16). Escribir para poder morir. M orir para poder escribir. La exigencia circular en Kafka, pero también en Uribe Arce. Encuentro de la suprema satisfacción en la suprema insatisfacción. Descubrimiento "en la extrema negatividad, en la muerte convertida en posibilidad, trabajo y tiempo, (de) la medida de lo absolutamente positivo" (Blanchot 2000:83).

De muerte, libro de "los estertores del poeta hablándose", contiene, con todo, el testimonio más profundo de la creación del vínculo del cual el poe- 
ta unido fuertemente a su muerte es juez, hace su muerte, se hace mortal y así adquiere el poder de hacer. La muerte, nuestra madremuerte de Losataúdes-Las erratas, deviene la musa misma que el poeta necesita cerca para escribir. Torsión del grito que corta la palabra en arte que es obra y vida. Aquí reside, sin duda, el efecto más creador de la metamorfosis de la extrema negatividad en positividad absoluta: "Ah, muerte, ven, te necesito / cerca para escribir mis versos, / dímelos tú, por más que adversos / me sean, dicta lo que escribo..." (Uribe 2000:35).. No sólo eso. La "posibilidad, trabajo y tiempo" de la muerte tiene una consecuencia aun más inesperada, más escandalosa en la historia poética de las aproximaciones a "nuestra madre muerte" en la poesía chilena. El escritor que pide a la muerte estar tan cerca de él, "como el feto de su madre a la semilla de su fruto" (Lihn), no le solicita decirle que está vivo sino llamarlo más bien "mi pequeñito" (Uribe 2000:35).

Los devenires en los cuales el escribir deviene otra cosa que escritor son, pues, múltiples en la poesía de Uribe Arce. Se deviene un mirón fascinado por la lección del cadáver de Cristo ("En la mente de Dios hay un gusano / que se prepara para conocerte. / Tú, mano sobre mano, / no crees en la muerte". "Eres polvo y serás / polvo y no dios ni rey", Uribe 1989:58), pero también un hombre a la intemperie que hace posible su propia muerte, un descubridor de la pequeña satisfacción que arrastra a unirse fuertemente a la muerte en el tiempo del silencio de Dios y del mesías muerto ("satisfacción de aceptarlo"), un futuro haz dehuesos que se prepara a morir solamente, un viejo en un estado incómodo que logra decir concretamente "desde que nací me fui al hoyo", y sobre todo, un pequeñito que dice a la muerte lo que sólo puede decir el mortal que ha logrado establecer con ella una relación de libertad: "te necesito cerca para escribir mis versos".

\section{MUERO DE AMOR POR UNA MUERTA}

El encuentro del poeta con la muerte en la poesía de Uribe Arce se actualiza, asimismo, a través de la experiencia de la muerte del otro: la mujer amada. La muerte del otro, acaecida en el cuerpo del otro, conduce nuevamente al sujeto poético a la visión de su propia-muerte. Antes de ello, sin embargo, se desciende al inframundo de la muerte del otro en un trance escatológico que recuerda el paseo de Dante o del mismo Orfeo en el Hades. El protagonista de ese tránsito se percata de su "imposibilidad de morir" como otra forma anticipada de muerte. El libro Verso bruto se desplaza, en este sentido, entre la visión del cuerpo muerto del otro y la visión de la propia-muerte. El yo del texto -signo huella del autor- es voz del cuerpo muerto, por ello, el sujeto hablará, insistentemente, desde el estado de su propia-muerte física. Ese cuerpo físico-poético dirá tanto a su Dios como a sus lectores: "Miradme:

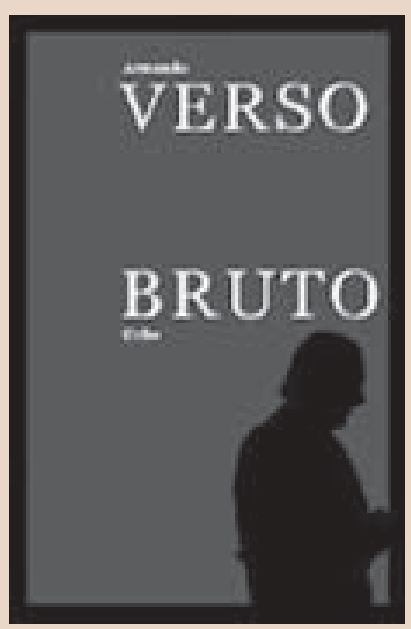


soy lo que Vos veis. / Tierra en mis ojos blancos. ¡Ciérralos! / Gusano soy, no hijo de rey" (Uribe Arce 2002a:121). Gusano soy. Ni cuerpo místico ni materia eternizada ni figura inmortal ni feliz cadáver en su tumba: cadáver soy. Punto y nada. La poesía deviene así elegía y epitafio del sujeto, voz del muerto desde la tumba, interrogación al dios callado desde el incómodo lugar que llamamos muerte: "Se me han cortado las venas, los nervios. / Me han abierto las manos y los pies. Todos los huesos me han contado. / Te digo amado, Amado; / no me respondes. Así es. / Me picotean unos cuervos" (Uribe Arce 2002a:124). La muerte-propia está ahí, inevitablemente posible desde que el sujeto mira la muerte reveladora del otro, sucedida de manera especial en el cuerpo, y no el alma metafísica de la amada.

Jankélévitch recuerda con razón que "no encontramos nada a lo que pudiéramos llamar una metafísica de la muerte; pero en cambio, uno se representa perfectamente una física de la muerte" (2002:17). Dicha representación, por ser una "evidencia de hecho", es descartada de plano, tanto por la tradición filosófica occidental como por la tradición poética chilena. La poesía de Uribe Arce constituye en este aspecto una fuga extrema de las concepciones filosóficas y poéticas que determinan nuestra comprensión de la muerte. La "física-poética de la muerte", que es a la vez una "metafísica de la muerte" entendida y enunciada desde la materialidad del cuerpo que muere, no duda por ello en mostrar la imagen más cercana de la muerte, en este caso, la muerte en el cuerpo amado:

Muero de amor por una muerta

divinidad humanizada

por mí, que ahora yace yerta.

Me quiere no me quiere nada.

La quiero aunque sea esqueleto

con la carroña alrededor.

A sus pies seré roedor

puñado de cenizas feto.

(Uribe Arce 2002a, 151).

La muerte del otro así divinizado revela, no obstante, la condición física, humana, de la muerte: el "esqueleto / con la carroña alrededor". De ese cuerpo-muerto el sujeto se nutre $y$, de esta forma, se vuelve consciente de su propia-muerte posible, como si la experiencia de la muerte del otro fuera exactamente la vivencia de la propia-muerte. Ambas formas de experimentar y comprender la muerte -en el otro y en uno mismo- componen el sentido ético de esta poesía que parte de la premisa de aceptar la muerte como acontecimiento y la mortalidad como definición de lo humano. Seguimos también en este aspecto el pensamiento de Maurice Blanchot, según el cual la muerte es una tarea impostergable, es decir, no aquello que está dado, sino 


\section{Los Ataúdes}

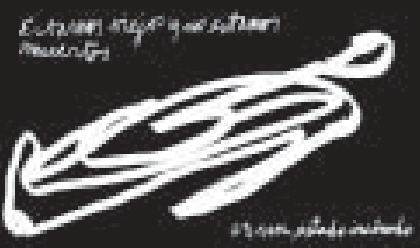

Armando Utibe Arce

\section{Las Erratas}

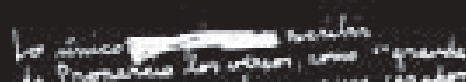

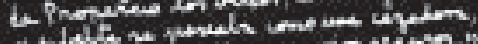

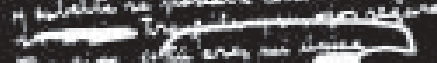

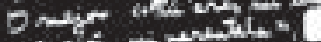

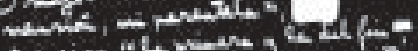

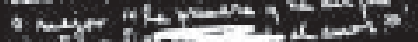

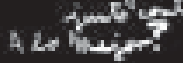

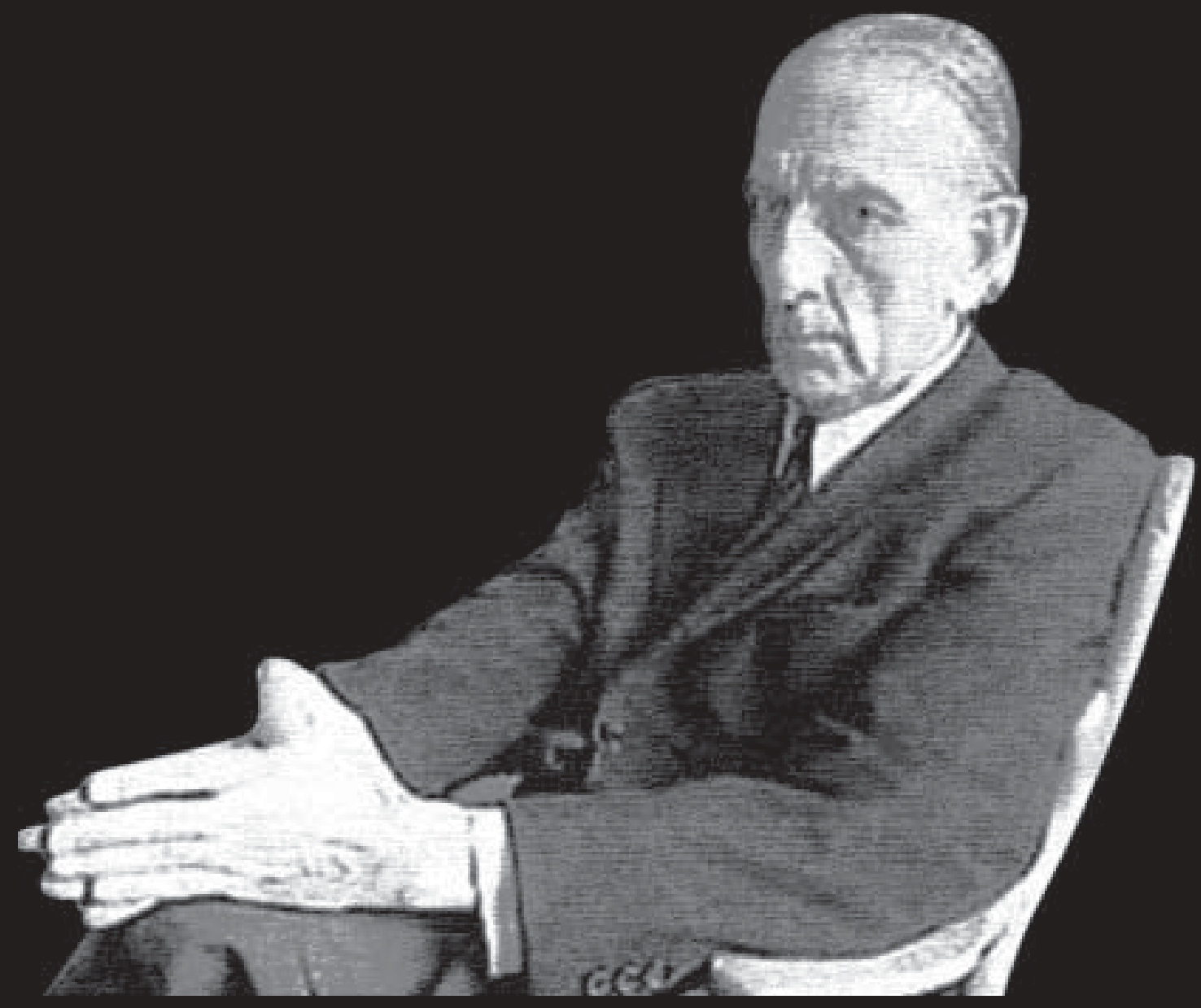

A. Uribe Arce 
aquello que hay que hacer posible o aquello que es necesario construir: "Se comprende que el objetivo de un hombre sea la búsqueda de la posibilidad de la muerte. Sin embargo, esa búsqueda sólo se vuelve significativa cuando es necesaria" (2000:87). La muerte, dice precisamente la poesía de Uribe Arce, es una necesidad innegable. El yo poético insiste por ello en hacer posible su propia-muerte, pasando de las visiones de la muerte en Cristo y la mujer amada a las visiones de la muerte-propia, donde la figura del autor también se desintegra. Señala Blanchot: "Morir uno mismo, de una muerte individual, individuo hasta el fin, único e indiviso: se reconoce ahí el duro núcleo que no quiere dejarse quebrar. Se quiere morir, pero a su hora y a su manera" (2000:113). Morir siendo fiel a uno mismo, pero también morir siendo fiel a la muerte. “¿Cómo hacer para morir sin traicionar esa alta potencia de la muerte? Doble tarea entonces: morir de una muerte que no me traicione a mí mismo; morir yo mismo sin traicionar la verdad y la esencia de la muerte" (Blanchot 2000: 118-119). Alta potencia que se ve y se reconoce en la muerte del otro, para luego hacerla parte del "supremo dominio" de la muerte-propia. Visión estremecida del cuerpo humano mortal de Cecilia, que invita, con su crueldad inocente, a mi propia-muerte.

\section{LA MUERTE-PROPIA: LA MUERTE DEL POETA}

Escribir para morir. Morir para escribir. Hay un lugar físico donde el autor hace posible su propia-muerte. Es el libro que deviene espacio mortal, lugar de proximidad inmediata con la muerte; tumba y epitafio, pero también memoria, huella y relación de la tarea humanizadora de establecer con la muerte relaciones de libertad. Figuración de "la Vieja" que lleva "no a la vida", pero también tenue luz de luciérnaga donde la conjunción del trabajo de morir con el trabajo de escribir hace posible la metamorfosis de la negatividad extrema en extrema positividad.

El mismo autor que desde 1998 se enclaustró en su casa "para bien o mal morir", según A.U.A en la solapa de De muerte explica, por lo demás, su física-poética de la muerte a través del devenir tercera persona del sujeto de la enunciación que habla de su propia-muerte más allá de la muerte y de la conciencia del yo. El espacio de la fosa en el que todos nos encontraremos es aquí el lugar propio donde el cuerpo se mira como la individualidad extraña y cercana que designamos con el nombre de el muerto. Es el devenir tercera persona que posibilita la propia-muerte del yo que firma Armando U ribe, nombre y signo revelador de la muerte física que el autor prevé en sí mismo.

El autor es, desde este punto de vista, la voz que muere en la obra. Es, como lo diría Foucault, el que representa "el papel del muerto en el juego de 
la escritura". Muerte que pasa, justamente, por la "desaparición de los caracteres individuales del sujeto escritor, mediante todos los ardides que establece entre él y lo que escribe" (1999:4). Las trampas, juegos, máscaras y devenires del yo son, en este caso, los ardides que relacionan inextricablemente al sujeto de la poesía horadada con la figura del autor, especialmente cuando dicho sujeto textual se designa con el mismo nombre propio del personaje empírico llamado Armando Uribe Arce. El nombre-propio, lo sabemos con Bennigton y Derrida, tiene una inquietante singularidad: lleva la muerte de su portador mientras garantiza su vida y le da seguridad durante y sobre su vida. "Se dirá, por consiguiente, que, incluso estando yo vivo, mi nombre señala mi muerte. Es ya portador de la muerte de su portador. Es ya el nombre de un muerto, la memoria anticipada de una desaparición" (1994: 124-126; 163). Memoria anticipada de una desaparición que explica, precisamente, la insistencia del poeta en vincular al sujeto de la enunciación con el nombre del autor, invitándonos así al acontecimiento poético en el que el propio nombre del autor anticipa su muerte para hacerla posible, tal como se aprecia en el poemario A peor vida:

No soy el viudo, soy el muerto que deja viudos sus alrededores. La agonía conozco, la del huerto. Lo sé muy bien: He muerto. No me llores. Armando Uribe yaces sin dolores. A estas alturas por debajo el león del polvo es un montón de roedores.

(2000:118).

La propia-muerte inscrita en el nombre del autor -así como el devenir tercera persona del sujeto- revela, sin embargo, el vacío total de la muerte después de la muerte. Vacío porque en ese hoyo desaparece irremisiblemente toda posibilidad de conciencia y todo yo dotado del poder de decir. Asimismo, tal como se invoca el nombre del poeta, el nombre de la amada, de Cecilia, señala una muerte anticipada y el vacío futuro y total del espacio que llamamos muerte. En ese lugar, dice el sujeto de esta poesía, "No hay anda. / No anda nadie. Yo no ando. / No hay tal yo" (Uribe Arce: 2000:23). Aquí, en esta ausencia, el sujeto poético se descubre como "abismo de lo propio" a la vez que la muerte se convierte en doblemente ajena y desconocida, porque "no estás en parte alguna y no eres muerte" (Uribe Arce 2000:65). La refutación de la "certeza irrefutable", anticipada en el nombre y en la firma del autor, es imposible:
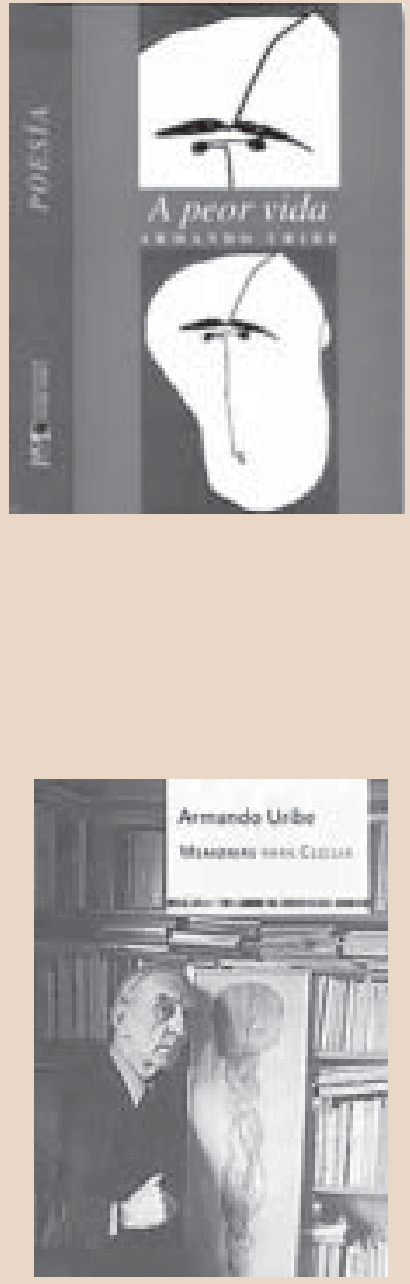
Muerte (se le habla) dónde está

(se le pregunta) tu aguijón.

Y tus trofeos cuáles son.

Veo unas pompas fúnebres mordidas por las ratas.

Muerte ¿de qué te jactas?

Lo que matas son restos; lo que raptaste ya no está.

(1999: 112).

Esos restos, no obstante, también hablan del "abismo de lo propio" y ese no estar ahí es un casi no estar intolerable e incómodo. Casi. Tal palabra define el proyecto físico y metafísico de esta escritura como "última oportunidad del ser antes del no-ser (que) marca, con un último destello, la infinita diferencia entre uno y otro" (Jankélévitch 2002:347). El sujeto no se escapa tan fácilmente de este estado futuro escatológico, porque no hay fugas del cadáver y porque la muerte que "roe y zapa" es, como no quiere decirlo Fernando Savater (1995), nuestra última conciencia del cuerpo en la muerte. Aquí reside el escándalo de la revelación en la poesía de Uribe Arce. El autor de Demuerte no poetiza en sentido estricto la figura del "moribundus, 'a punto de' morir". Tampoco la figura del "moriens, 'en trance de' morir". Poetiza la figura del "mortuus, que designa un estado" (Jankélévitch 2002:348349). Nada hay en este estado de alteridad radical. "No hay tal yo", ni muerte siquiera, como lo piensa el filósofo, "iy sin embargo ese otro mundo siempre distinto a todo, no es propiamente hablando ni otro ni siquiera un mundo!" (Jankélévitch, 2002:351). La poesía de Uribe Arce muestra aquí su significación estética, ética y política más provocadora como ficción escatológica del otro mundo paradójicamente posible. Buscamos ese otro pueblo en el que los huesos de los muertos hacen "eslabones fuertes" aún desgagados con la llama intensa de la vida porque la propia historia no lo ha podido fundar. Buscamos ese pueblo en el "abismo de lo propio" y más allá del instante mortal. El armónico país de los muertos, con sus cuerpos transmutados en almas, "sin el celo fronterizo de que hace gala el mundo", es el pueblo que falta. Objetivo último de la literatura, según Deleuze: "Poner de manifiesto en el delirio esta creación de una salud, o esta invención de un pueblo, es decir, una posibilidad de vida" (1996:16). Ese pueblo que el poeta Uribe Arce prefigura reinventándolo de epitafio en epitafio y de poema en poema: "Todos estaremos en esa última casa".

\section{REFERENCIAS}

Aldunate, Pedro. 2004. "La construcción autorial de Armando Uribe Arce: el autor, la obra y la muerte". Tesis de Magíster en Literatura Hispanoamericana, Universidad de Concepción, Concepción, Chile. 
Bataille, Georges. 1992. El erotismo. Barcelona: Tusquets Editores, S.A.

Bennington, Geoffrey y Jacques Derrida. 1994. Jacques Derrida. Madrid: Ediciones Cátedra S.A.

Blanchot, Maurice. 2000. El espacio literario. Barcelona: Paidós.

Cioran, E. M. 1998. La caída en el tiempo. Barcelona: Tusquets Ediciones.

Deleuze, Gilles. 1996. Crítica y clínica. Córdoba: Alción Editora.

Deleuze, Gilles y Claire Parnet. 1997. Diálogos. Valencia: Pre-Textos.

Foucault, Michel. 1999. "Qué es un autor", en Literatura y conocimiento. En: http://www.saber.ula.ve/db/ssaber/Edocs/centros_investigacion/csi/publicaciones/papers/davila-autor.pdf

Goic, Cedomil. 2003. Vicente Huidobro. O bra poética. Madrid; Barcelona; La Habana; Lisboa; París; México; Buenos Aires; Sao Paulo; Lima; Guatemala; San José; Caracas: ALLCA XX.

Jankélévitch, Vladimir. 2002. La muerte. Valencia: Pre-Textos.

Kristeva, Julia. 1990. "El Cristo muerto de Holbein”. En Fragmentos para una historia del cuerpo humano. Parte Primera, Madrid: Taurus, pp. 247-278.

Lihn, Enrique. 1989. Diario de muerte. Santiago: Editorial Universitaria.

Mistral, Gabriela. 1992. Antología mayor. Poesía, Tomo I. Santiago: Cochrane S.A.

Muñoz, Luis y Oelker, Dieter. 1995. Diccionario de movimientos y grupos literarios. Concepción: Ediciones Universidad de Concepción.

Neruda, Pablo. 1967. O bras completas V. I. Buenos Aires: Editorial Losada, S.A.

. 1993. Obras II y III. Buenos Aires: Editorial Losada, S.A.

Parra, Nicanor. 1985. Hojas deParra. Santiago, Chile: Ediciones Ganymedes Ltda.

Pezoa Véliz, Carlos. 1912. Poesías. Santiago, Valparaíso, Chile: Biblioteca Chilena Moderna.

Savater, Fernando. 1995. "La muerte”, en Invitación a la ética. Barcelona: Editorial Anagrama, S.A.

Steiner, George. 1995. “El escándalo de la revelación”, en revista Confines, abril, año I, No I, pp. 65-80.

Triviños, Gilberto. 1996. "Las metamorfosis de la Muerte semejante a Diana en la poesía de Rubén Darío, Vicente Huidobro y Nicanor Parra”, en Acta Literaria No 21, pp. 75-92.

. 2001. "Perdices y panteras en Samarcanda". En Varios, Psicoanálisis parra nada. Antipoesía \& Psicoanálisis”. Santiago de Chile: Ediciones CESOC, pp, 120-145.

.2005. "Se lee en la pantalla: solo para ti”. En Francisca Noguerol (coord.), Enrique Lihn, Contra el canto dela goma de mascar: Asediosa Enrique Lihn. Sevilla: Secretariado de Publicaciones de la Universidad de Sevilla, pp. 289-302.

Uribe Arce, Armando. 1989. Por ser vos quien sois. Santiago, Chile: Editorial Universitaria, S.A.

. 1999. Lo ataúdes/Las erratas. Santiago, Chile: Be-uve-dráis Editores. 2000. A peor vida. Santiago, Chile: Lom Ediciones. . 2002a. Verso bruto. Santiago, Chile: Be-uve-dráis Editores. 
2002b. M emorias para Cecilia. Santiago, Chile: Editorial Sudamericana.

2004. De muerte. Santiago, Chile: Editorial Universitaria, S.A.

$\min$ 